\title{
The Current Status of Cutaneous Leishmaniasis in Morocco
}

\section{Fas'ta Kutanöz Leishmaniasis' in Güncel Durumu}

\author{
Zineb Tlamçani ${ }^{1}$, Mohammed Er-Rami² \\ 'Laboratory of Provincial Hospital Center of Taroudant, Morocco \\ ${ }^{2}$ Department of Parasitology, Faculty of Medicine and Pharmacy of Fes, Morocco
}

\begin{abstract}
Cutaneous leishmaniasis (CL) is a public health problem on a global level because it affects the population of 88 countries. In Morocco, it is widely distributed, caused by Leishmania tropica, Leishmania major and Leishmania infantum rarely. The geographical distribution of different forms of leishmaniasis in Morocco is linked to well described bioclimatic zones. Over the past two decades, the epidemiological situation of CL has changed significantly. It acquire an increasingly epidemic status with geographic expansion to previously free areas and the emergence of overlapping foci of cutaneous leishmaniasis and visceral leishmaniasis in several provinces of Morocco. In this review the evolution of the epidemiological situation and epidemiological factors which influenced the course of it in the past two decades will be reported. (Turkiye Parazitol Derg 2014; 38: 5-8)
\end{abstract}

Key Words: Cutaneous leishmaniasis, epidemiology, Morocco

Received: 07.11.2013

Accepted: 21.11 .2013

\section{ÖZET}

Kutanöz Leishmaniasis (KL) 88 ülkenin nüfusunu etkilediği için küresel düzeyde bir halk sağlığı sorunudur. Fas'ta, yaygın olarak dağılmışır, Leishmania tropica, Leishmania major ve nadiren Leishmania infantum etkendir. Fas'ta Leishmaniasis'in farklı formlarının coğrafi dağılımı iyi tanımlanmış biyo-iklimsel bölgelerle bağlantılıdır. Son yirmi yılda, KL'nin epidemiyolojik durumu önemli ölçüde değişmiş̧ir. Önceden muaf olan bölgelere coğrafi genişleme ve Fas'ın çeşitli illerinde kutanöz Leishmaniasis ve visseral Leishmaniasis odaklarında örtüşmenin çıkması ile giderek epidemik bir görünüm kazanmaktadır. Bu derlemede son yirmi yıl içinde epidemiyolojik durumun evrimi ve seyrini etkileyebilecek epidemiyolojik etkenler rapor edilecektir. (Turkiye Parazitol Derg 2014; 38: 5-8)

Anahtar Sözcükler: Kutanöz Leishmaniasis, epidemiyoloji, Fas Geliş Tarihi: 07.11.2013

Kabul Tarihi: 21.11.2013

\section{INTRODUCTION}

Cutaneous leishmaniasis (CL) is a protozoan infection caused by protozoa of the genus Leishmania. The disease is characterized by chronic skin lesions, leaving permanent scars with deformation of the infected area. It is distributed in many tropical and subtropical countries $(1,2)$. It is a concern for WHO because it is affecting the population of 98 countries. Its prevalence is estimated at 12 million people worldwide. There are 1-2000000 new cases each year and of these, 300.000 are skin forms $(3,2)$. In Morocco, this skin disease is widely distributed as three nosogeographic entities. The geographical distribution of different forms is related to well described bioclimatic zones. According to Rioux et al. (4) the bioclimate of the vector determines the distribution, density, and therefore the prevalence of the disease.

Address for Correspondence / Yazışma Adresi: Dr. Zineb Tlamaçani, Department of Parasitology, Faculty of Medicine and Pharmacy of Fes, Morocco. Phone: (212)0663037764 E-mail: tzineb@hotmail.fr DOI:10.5152/tpd.2014.1401

CCopyright 2014 Turkish Society for Parasitology - Available online at www.tparazitolderg.org

(C) Telif hakkı 2014 Türkiye Parazitoloji Derneği - Makale metnine www.tparazitolderg.org web sayfasından ulaşılabilir. 
Anthroponotic CL (ACL) caused by L. tropica with seven zymodemes (MON-102, MON-107, MON-102, MON-109, MON-112, MON-113, MON-122 and MON-123). This form was identified in 1987, and since 1997, has been considered as a major threat to public health $(5,6)$. It is widespread in semi-arid regions, provinces in central and western slopes of the Atlas Mountains, from Azilal in the center up to Essaouira in the west and AgadirGuelmim in the South (7). The vector responsible for transmitting this form depends on the circulating zymodeme. It is shown that Phlebotomus sergenti ( $P$. sergenti) is capable of transmitting the zymodemes MON 102, MON 107, MON 122 and MON 123 (6). Zymodeme MON 102 is frequent since it was responsible for an outbreak of foci in Taza in 1995 (8) and in 2000 the infection of 300 people in the province of Chichaoua by L. tropica MON 102 was reported (9).

\section{Zoonotic CL due to Leishmania major ( $\mathrm{ZCL}$ )}

The disease is observed in arid zones in the palm groves of the southern foothills of the Anti-Atlas and High Atlas (6). Its distribution is related to the presence of the commensal rodent Meriones shawi grandis, which acts as a reservoir of the parasite. Its transmission is ensured by Ph. papatasi as the vector (10). The biochemical identification was identical for all strains isolated from the reservoir, the man and the vector, as L. major MON 25. This CL has been known since 1914 (11). At first the disease was known by a few sporadic cases $(10,12)$. Later, this disease has taken an epidemic form separated by calm periods (5).

\section{$C L$ by $L$. infantum}

The first case of this form was described in France (13). Following this, its presence has been reported in most foci of canine leishmaniasis and human VL in the Mediterranean area. In Morocco, the first case was described in the central Rif in Taounate. Biochemical identification of the parasite showed that it is $L$. infantum MON 24 (14). In 2007 Rhajaoui et al. (15) reported an outbreak of CL in Morocco caused by L. infantum, with 8 cases in Sidi Kacem. This study confirmed an overlap of $C L$ and $V L$ in several provinces in central Morocco, the anthroponotic foci of LC due to $L$. tropica found in Fez and Taza, not far from foci of VL in Sidi Kacem. In addition, several cases of canine VL caused by $L$. tropica have been reported in areas where canine $V L$ is caused by L. infantum.

\section{Epidemiological News in Morocco}

The epidemiology of cutaneous leishmaniasis (CL) in Morocco has changed considerably over the past two decades (Figure 1). The incidence of CL due to L. tropica increased between 2002 and 2012. According to statistics from the Ministry of Health (16), the number of cases during the year 2012 is 2137 compared to 1130 cases recorded in 2002 (Figure 2).

However the evolution of ZCL has showed some fluctuation in recent years. Since 2003, there has been a revival of old foci of $L$. major with an increase in the number of cases reported annually. The maximum peak was reached in 2010 (6444 cases) (17). Due to the implementation of the response strategy in the fight against leishmaniasis between 2010-2012 which strengthened the struggle against the reservoir, the incidence of this zoonosis declined sharply and decreased from 2219 cases in 2011 (18) to 740 cases in 2012
In 2008, two new foci of ACL appeared outside the known risk areas, previously defined by the Public Health Services. The first case was in the north-east of the country, on the eastern hill of the Middle Atlas Mountains, in a sub-humid region (province Boulmane) and the second in the south-east of the country, on the eastern slopes of the mountains high Atlas, in a Saharan region (province Tinghir) (19). The Chafika faraj study reported an increase in the abundance of $P$ h. sergenti, even in habitats where the species was less common (wet and Saharan zones) and an extension of his term of office.

These results may explain the increase of the incidence of $\mathrm{CL}$ caused by L. tropica in Morocco and its extension to new non -endemic areas (Boulmane and Tinghir). We think that the emer-

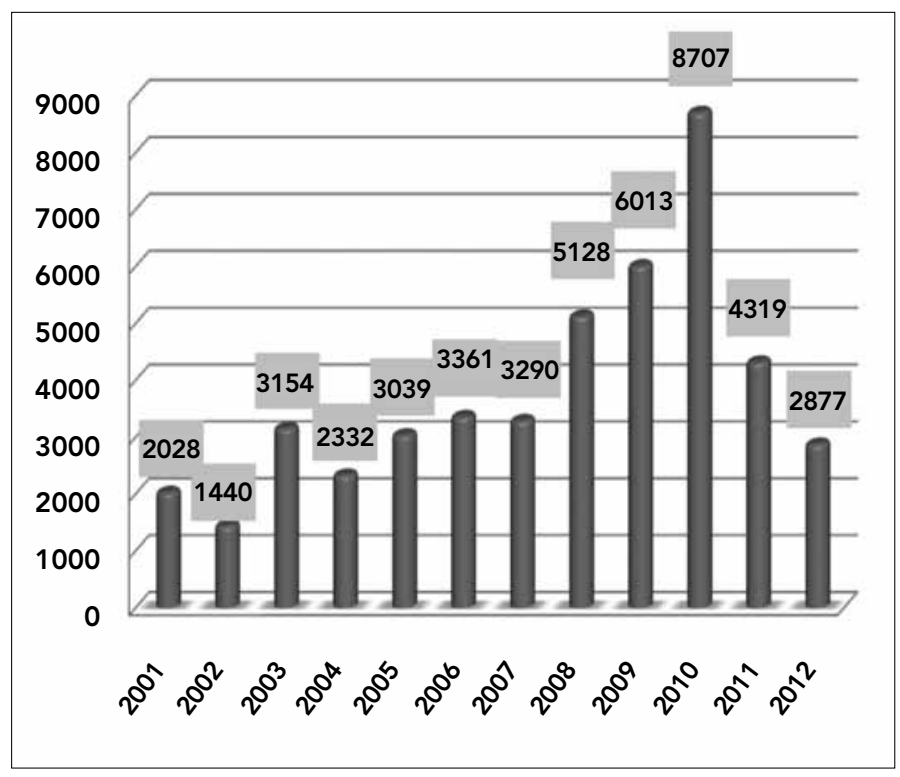

Figure 1. The evolution of the number of cutaneous leishmaniasis cases between 2001 and 2012

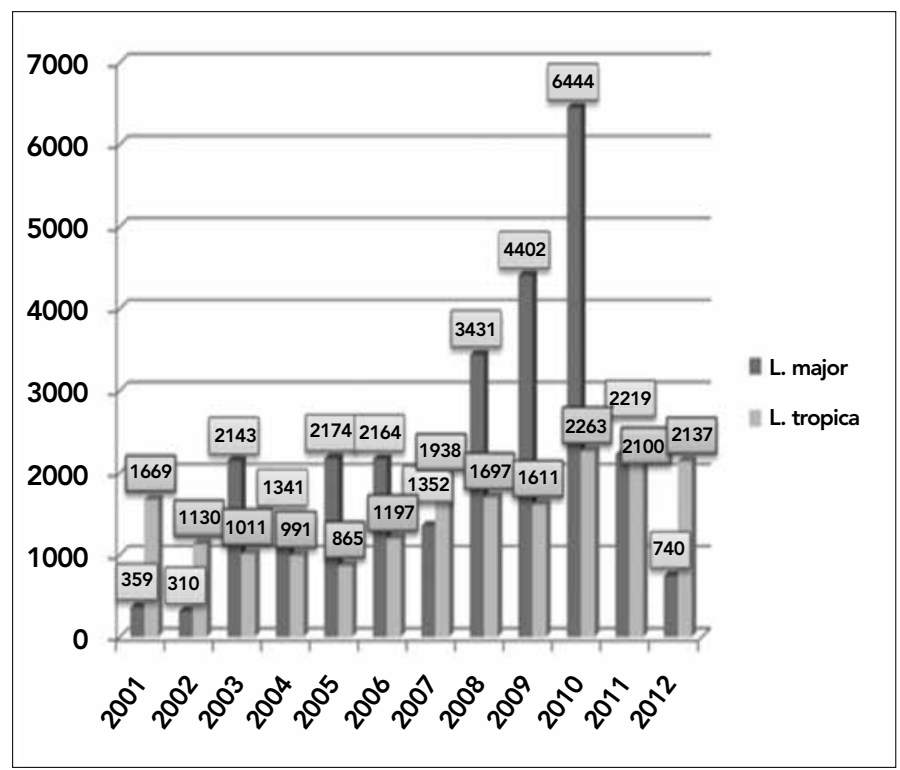

Figure 2. The evolution of the incidence of $C L$ caused by $L$. major and L. tropica between 2001 and 2012 
gence of CL by L. tropica in Tinghir (Saharan region) could be related to local changes as follows:

Local changes. Indeed, this region has experienced a high level of environmental degradation in recent years. The human population has increased, particularly in areas where housing conditions are unfavorable. The establishment of animal colonies near households and population movement from neighboring countries to endemic areas has favored the transmission of leishmaniasis in this province (19). Moreover, the Ministry of Health concluded that the epidemiological situation was marked by outbreaks of CL caused by Leishmania tropica in urban and sub -urban areas which have a rural characteristic as well as an increase of CL caused by Leishmania major in traditional homes where outbreaks are interspersed with calm periods. Therefore, the epidemiology of $C L$ is changing to epidemic conditions with geographic expansion to leishmaniasis free zones (16). In other neighboring countries around the Mediterranean, similar changes in the epidemiological situation has also been reported. In Algeria, an expansion of distribution areas of the $C L$ and changes in risk factors have recently been noted (20). In Tunisia, epidemiology of CL has been marked in recent years by an increase in the incidence and extension of their distribution areas with the co-transmission of more than one form in somefoci (21). It is also reported that leishmaniasis has become widespread in many European countries in recent years, especially in the Mediterranean region. Most reported outbreaks have been linked to global and local changes resulting from climate change or the growth of human populations and their activities (22). The effects of climate change and instability on the transmission of vector-borne diseases such as leishmaniasis can be the result of several variables such as minimum and maximum daily and average temperature , number of days with a temperature above a certain threshold , the relative humidity at different times of the day and through the seasons, the accumulated rainfall in different periods prior to the date of interest, soil moisture and changes associated with human land use. In addition to climate change and instability, other variables such as water management, growth of the human population and urbanization, chemical pollution and the movement of people should be taken into account (22). As the dispersion of reservoirs through social and business networks, such as the introduction of high-risk of L. tropica in southern Italy, which was linked to the importation of infected dogs from North Africa and the presence of the vector (23).

\section{CONCLUSION}

Changes in the epidemiological situation of CL in Morocco, in recent years, such as the expansion of distribution areas and the coexistence of two forms in some foci are similar to those reported in many countries around the Mediterranean. These changes may be related to climate change and the growth of the human population observed during the last decade in Morocco, and in neighboring countries.

Peer-review: Externally peer-reviewed.

Author Contributions: Concept - Z.T., M.E.; Design - Z.T., M.E.; Supervision - Z.T.; Funding - Z.T., M.E.; Materials - Z.T., M.E.; Data
Collection and/or Processing - Z.T., M.E.; Analysis and/or Interpretation - Z.T.; Literature Review - Z.T.; Writing - Z.T.; Critical Review - Z.T.; Other - Z.T., M.E.

Conflict of Interest: No conflict of interest was declared by the authors.

Financial Disclosure: The authors declared that this study has received no financial support.

Hakem değerlendirmesi: Dış-bağımsız.

Yazar Katkıları: Fikir - Z.T., M.E.; Tasarım - Z.T., M.E.; Denetleme - Z.T.; Kaynaklar - Z.T., M.E.; Malzemeler - Z.T., M.E.; Veri toplanması ve/veya işlemesi - Z.T., M.E.; Analiz ve/veya yorum - Z.T.; Literatür taraması - Z.T.; Yazıyı yazan - Z.T.; Eleştirel Inceleme Z.T.; Diğer - Z.T., M.E.

Çıkar Çatışması: Yazarlar herhangi bir çıkar çatışması bildirmemişlerdir.

Finansal Destek: Yazarlar bu çalışma için finansal destek almadıklarını beyan etmişlerdir.

\section{REFERENCES}

1. Amro A, Gashout A, Al-Dwibe H, Zahangir Alam M, Annajar B, Hamarsheh O, Shubar H, Schönian G. First Molecular Epidemiological Study of Cutaneous Leishmaniasis in Libya. PLOS Neglected Tropical Disease 2012; 6: 1-6. [CrossRef]

2. WHO: Control of the leishmaniases, WHO Tec Rep Ser 2010, 949: 1-186.

3. Díaz Sánchez J, Barrientos Serrano S, Morell Mañas S. Leishmaniasis cutánea. FMC 2012; 19: 117-28.

4. Rioux JA, Lanotte G, Petter F, Dereure J, Akalay O, Pratlong F, et al. Les leishmanioses cutanées du bassin Méditerranéen occidental. De l'identification enzymatique à l'analyse éco-épidémiologique. L'exemple de trois foyers, tunisien, marocain et français. In: Rioux JA, editor. Leishmania taxonomie et phylogénèse. Applications éco-épidémiologiques. Colloque International Centre National de la Recherche Scientifique, Institut National de la Santé et de la Recherche Médicale (CNRS INSERM) 1984. L'Institut Méditerranéen d'Etudes Epidémiologiques et Ecologiques (IMEEE), Montpellier. 1986; p. 365-95.

5. Guessous-Idrissi N, Berrag B, Riyad M, Sahibi H, Bichichi M, Rhalem A. Short report: Leishmania tropica: etiologic agent of a case of visceralizing canine leishmaniasis in north Morocco. Am J Trop Med Hyg 1997; 57: 172-3.

6. Rhajaoui M. Human leishmaniases in Morocco: A nosogeographical diversity. Pathol Biol (Paris) 2011; 59: 226-9. [CrossRef]

7. Guilvard E, Rioux JA, Gallego M, Pratlong F, Mahjour J, Martinez-Ortega $E$, et al. Leishmania tropica au Maroc. Ann Para Hum Comp 1991; 66: 96-9.

8. Bichichi M, Riyad M, Guessouss-Idrissi N. Isoenzyme characterization of Leishmania tropica in the emerging epidemic focus of Taza (North Morocco): epidemiological corollaires. Trans Roy Soc Trop Med \& Hyg 1999; 92: 660-3.

9. Rhajaoui M. Leishmaniases in Morocco. Leish-Med metting on Molecular epidemiology of leishmaniases, Irbid, Amman, September 2005

10. Prudhomme J, Gunay F, Rahola N, Ouanaimi F, Guernaoui S, Boumezzough $A$, et al. Wing size and shape variation of 
Phlebotomus papatasi (Diptera: Psychodidae) populations from the south and north slopes of the Atlas Mountains in Morocco. J Vector Ecol 2012; 37: 137-47. [CrossRef]

11. Foley $\mathrm{H}$, Vialatte $\mathrm{C}$. Existence dans le Sud marocain du bouton d'orient à l'état endémique. Bull. Soc. Path. Exot 1914; 7: 114-5.

12. Guessous-Idrissi N, Chiheb S, Hamdani A, Riyad M, Bichichi M, Hamdani S, et al. Cutaneous leishmaniasis: an emerging epidemic focus of Leishmania tropica in North Morocco. Trans $\mathrm{R}$ Soc Trop Med Hyg 1997; 91: 600-3. [CrossRef]

13. Rioux JA, Lanotte G, Maazoun R, Perello R, Pratlong F. Leishmania infantum Nicolle, 1908, the agent of the autochthonous oriental sore. Apropos of the biochemical identification of 2 strains isolated in the eastern Pyrenees. C R Seances Acad Sci D 1980; 291: 701-3.

14. Rioux JA, Mahjour J, Gallego M, Dereure J, Perieres J, Lahmrani $A$, et al. Leishmaniose cutanee humaine a Leishmania infantum Mon 24 au Maroc. Bull Soc Fran Parasito 1996; 14: 2.

15. Rhajaoui M, Nasereddin A, Fellah H, Azmi K, Amarir F, Al-Jawabreh A, et al. New Clinico-epidemiologic Profile of Cutaneous Leishmaniasis, Morocco. Emerg Infect Dis 2007; 13: 1358-60. [CrossRef]

16. Anonymous, Etat de santé de la population marocaine, Ministère de la Santé. 2012.

17. Anonymous, Etat d'avancement des programmes de lutte contre les maladies parasitaires. Rapport annuel d'activité,
Direction de l'Epidémiologie et de Lutte contre les Maladies Ministère de la Santé. 2010.

18. Anonymous, Etat d'avancement des programmes de lutte contre les maladies parasitaires. Rapport annuel d'activité, Direction de l'Epidémiologie et de Lutte contre les Maladies (DELM) - Ministère de la Santé. 2011.

19. Faraj C, Adlaoui E, Ouahabi S, El Kohli M, El Rhazi M, Lakraa L, et al. Distribution and Bionomic of Sand Flies in Five Ecologically Different Cutaneous Leishmaniasis Foci in Morocco. ISRN Epidemiology 2013: 1-8

20. Mihoubi I, Picot S, Hafirassou N, Monbrison F. Cutaneous leishmaniasis caused by Leishmania tropica in Algeria. Trans R Soc Trop Med Hyg 2008; 102: 1157-9. [CrossRef]

21. Ben Abda I, aoun K, Ben Alaya N, Bousslimi N, Mokni M, Bouratbine A. Données Epidémiologiques, Cliniques et Parasitologiques Actualitées de La Leishmaniose Cutanée en Tunisie. Revue Tunisienne d'Infectiologie 2009; 2: 31-36.

22. Ready PD. Leishmaniasis emergence and climate change. Rev Sci Tech 2008; 27: 399-412.

23. Gramiccia M, Gradoni L. The current status of zoonotic leishmaniases and approches to disease control. Int J Parasitol 2005; 35: 1169-80. [CrossRef] 